The Social Sciences 14 (1): 1-8, 2019

ISSN: $1818-5800$

(C) Medwell Journals, 2019

\title{
The Impact of IFRS Convergence on the Market Value of Equity on Trade, Goods and Services Companies Listed on the Indonesia Stock Exchange
}

\author{
Bakti Setyadi, Bochari Rachman and Fitriasuri \\ Faculty of Economics and Business, University of Bina Darma Palembang, Jawa, Indonesia
}

\begin{abstract}
The development of multinational companies encourages the development of global capital markets and demands better disclosures in financial reporting. Therefore, the International Financial Reporting Standard (IFRS) issued by the International Accounting Standards Board (IASB) has been selected as the basis for the development of financial reporting standards through the convergence process. The changes of the financial standards provide options in determining the accounting policies used to calculate the company's value for investors. This research examines the impact of implementation of IFRS convergence on Market Value of Equity (MVE) and influencing determinants includes Earning Per Share (EPS), Equity per Share (EQPS), Price Per Share (PPS) by using paired t-test (paired-sample t-test) between the data before and after the convergence of IFRS. The method used is a survey method by using secondary data with quantitative analysis in the sector of trade in goods and services listed on the Indonesian Stock Exchange. The result shows that the convergence of IFRS did not have a significant impact on average changes of the value of EPS, EQPS, PPS and MVE. In other words, the convergence of IFRS had no impact on changes in the value of the said four variables. Furthermore, the correlation test result shows that the convergence of IFRS has relation to the value formation of market value of equity and price per share after the implementation of IFRS. Instead, the convergence of IFRS did not contribute to the value formation of earning per share and equity per share after IFRS implementation.
\end{abstract}

Key words: Development, convergence, IFRS, the effects, the value of the company, IASB

\section{INTRODUCTION}

The development of multinational companies has been pushing the development of global capital markets and increase the demands on a better financial report disclosure. However, the disclosure relates to the development of systems, practices and accounting standards of a country and is influenced by sources of funding, the legal system, taxation, political and economic bonds, inflation and the development level of economy, education and culture (Choi and Meek, 2005). To support uniform financial report disclosures in multinational companies and in the global capital market, the International Financial Reporting Standard (IFRS) which was issued by the International Accounting Standard Board (IASB) has been currently chosen as the basis for the development of local standards. There are at least 15,000 companies which are active in stock exchange and 123 countries which are using IFRS adjusted in accordance with the conditions of each country (Collemi, 2011). This shows that the companies in the world have a quite high on using IFRS which can improve their performance and public accountability.

Financial reporting has been significant as a source of information for their investment decision (Chee et al.,
2016). The implementation of the global standard will lead the companies to produce financial reports with an international quality. Some previous studies showed that the IFRS accountiong standards are much better than domestic accounting standards as they can increase the comparability and contribute effectively to the low cost of capital (Barth, 2008) as well as improve the corporate environmental information(Barth, 2008; Daske et al., 2008; Ashbaugh and Pincus, 2001). In addition to this, IFRS is believed to out perform the domestic accounting standards it increase financial report disclosures and transparency (Daske et al., 2008). On the other hand, the results of different studies indicate that the adoption of high-quality accounting standards does not automatically lead to high quality financial reporting (Burgstahler et al., 2006; Cairns, 1999; Street and Gray, 2001). One cause is the use of discreation of reporting formed by reporting incentives (Ball et al., 2003) and company level factors (Ball and Shivakumar, 2005; Burgstahler et al., 2006).

The fundamental difference between IFRS and local standards lies in the principle-base concept which is used to replace the rule-base principle. This change created differences in the values of assets and invested capital which are determined by the accounting fair (Blanchette and Desfleurs, 2011; Chua and Taylor, 2008).

Corresponding Author: Bakti Setyadi, Faculty of Economics and Business, University of Bina Darma Palembang, Jawa, Indonesia 
The values of assets and invested capital have the potential to increase or decrease. With the changes, the financial information and the viewpoints of investors have also undergone a change. The higher the results that the investors expect to accrue, the higher the value of the company in the eyes of investors. According to Weston and Copeland (Ayu, 2014) the value of a company is the market value of the company or project that is determined from the natural capitalization level of the expected results of that company or project. The value of a company is also a certain condition achieved by that company as an overview of the society beliefs on the company after going through a process of activities over the past few years, i.e., since, the company was established until now (Bambang, 2010a, b).

For a company listed on the stock exchange, the market value of that company is reflected in the share price (Price per share). The better the value of the company in the eyes of the society is the higher share price of the company will be.

The rise of the share prices indicates that investors have confidence that the company will provide the return they expected. Ohlson Model (Ohlson, 1995) shows that the value of the stock market is also related to the earnings per share.

Indonesia Stock Exchange (IDX) is the only stock exchange in Indonesia. Historically, the stock market has existed long before Indonesia became independent, exactly, since, Dutch colonial era in 1912 in Batavia. At that time, the capital market when it was established by the Government of Dutch East Indies in the interests of the colonial Government or VOC. However, the capital market did not develop and run as expected and became dormant. This was caused by several factors such as World War I and II and the transfer of power from the colonial Government to the Government of the Republic of Indonesia. The Government of the Republic of Indonesia reactivated the capital market in 1977. At the beginning of the development of the stock exchange in Indonesia, Jakarta Stock Exchange, Semarang Stock Exchange and Surabaya Stock exchange were eventually merged and became Indonesia Stock Exchange in 2007. Currently, based on 2014 IDX taxonomy, there is a classification of sectors and subsectors based on the similarity of financial report format. Based on 2014 Fact book, the classification of the sectors and subsectors based on 2014 Fact Book is divided into 8 large parts of industry with 489 companies registered. All companies incorporated in IDX have been required to implement the results of the convergence of IFRS, since, January 1, 2012. Based on the above explanation, the writers did a study to find out the impact of the IFRS convergence on the market value of the company or the market value of equity. The writers limit the scope of the study by focusing on trading and service companies in Indonesia Stock Exchange.

IFRS (International Financial Reporting Standard) is the international accounting standards issued by the International Accounting Standards Board (IASB). Most standard contents of IFRS are the International Accounting Standards (IAS) drawn up by the four major world organizations, namely the International Accounting standards body (IASB), Commission of the European Communities (EC), the Organization of the international Capital Markets (IOSOC) and the Federation of International Accounting (IFAC) (Situmorang, 2009). The International Accounting Standards Board (IASB), formerly known as the International Accounting Standards Committee (IASC) is an independent agency that is in charge of drawing up global accounting standards which are of high quality, understandable and can be compared (Choi et al., 1999). IAS started in 1973 up to 2001 and continued to the IFRS since the formation of the IASB.

IFRS is accounting reporting standards which were created with an emphasis on professional revaluation, disclosures and transparency regarding the economic substance of the transaction and the explanation to reach certain conclusions. IFRS also appears as the result of the demands of globalization in which many businessmen in a country (especially, multinational corporations) are involved in a cross country business. Therefore, an international standard that could be applied equally in all countries is required to facilitate the process of business reconciliation and consolidation.

In Indonesia, accounting has been applied, since, 1642, especially, after the Cultivation System was abolished and the development of capital investments by private entrepreneurs in Netherlands. At first was of continental system, like the one used in the Netherlands which was called book keeping (Soemarso, 1992). Bookkeeping concerns with constructive processes starting from recording, compaction, categorization and other activities aimed at creating accounting information based on the data. Since, the 1950's, accounting in Indonesia refers to the accounting system embraced by America, i.e., GAAP and in 2008 the Government of Indonesia initiated IFRS as Indonesia's new accounting standards. It was fully implemented in 2012.

IFRS convergence refers to a mechanism or stage committed by country to replace its national accounting standards with IFRS, this process is a lot more to be found in developing countries (Nobes and Parker, 2010). Indonesia itself has fully adopted IFRS in 2012. By fully adopting IFRS, financial reports made under the Statement 
of Financial Accounting Standards (PSAK) requires no significant reconciliation with financial reports based on IFRS.

The IFRS convergence can have an impact on the measurement aspects of financial reporting items such as net income and equity (Syofian, 2010) as well as on improving the quality of financial reports (Daske and Gebhardt, 2006). Meanwhile, the adoption of IFRS can also identify the earning management on financial reports (Butler et al., 2004). On the other hand, the adoption of IFRS has a significance effect on shareholder equity, net income and liquidity (Tsalavoutas and Evans, 2010). However, other studies have also found that the application of convergence does not necessarily improve the value of a company. It was found out that the IFRS convergence did not cause revision in relation to the financial reporting for the local stock market operator because there was gap between the book value and the wider market value when IFRS was applied (Callao et al., 2007) and because there had not been any profit in short term financial reporting. The increase of benefits is estimated to be achieved in a medium to long term. IFRS is also said to not affect the book value (Hung and Subramanyam, 2007) and produce no statistically significant difference between the market value of local standards and IFRS-based market value (Terzi et al., 2013).

\section{MATERIALS AND METHODS}

The design of this research was created to describe the overall process ranging from design and implementation of research including the collection and analysis of data that is used to describe the research (Arfan, 2008). Seen from its goal, this research is an applied research whose results which can be used both by individuals and companies to obtain information that can be used to solve problems (Husein, 2010). Whereas, if viewed from this research, design methods is ex post facto research, i.e., research with investigations in a systematic empirical where researchers have no direct control toward its independent variables because the phenomenon is difficult to manipulate (Syofian, 2010). Based on the level of empirical research, this research belongs to the category of associative and comparative research or relationship. Being comparative is to compare between variables while being associative is to find out the relationship between two or more variables. In addition, there are also descriptive researches, to find out the value of a variable, whether one variable (independent) or more without making a comparison or an association with other variables. In terms of its philosophy paradigm, this research is a type of research that is compiled to build hard sciences based on the objectivity and controls which operate with strict rules, including logic, truth, law, axiomatic and prediction (Husein, 2010). The researchers defined the variables, developed instruments, collected data, did the analysis and conducted generalization carefully and objectively. The quantitative method is known as the scientific method (scientific) because it has meet the scientific norms, i.e., concrete/empirical, objective, measurable, rational and systematic.

The types of data used are secondary data in the form of financial statements of some companies listed on the stock exchange and related journals. According to Kurtz, MacKenzie and Snow, secondary data are the data that come from the previous publication or the data that are already compiled by certain sources. This research data were classified as cross-section data, i.e., data collected at a certain period on multiple objects with the aim to describe the circumstances of those objects (Syofian, 2010). However, the researchers also used time series data, i.e., types of data which are coherently differentiated into time series from time to time on an object with the aim to describe the development of that object. The main data sources of this research derive from financial reports of trading and service companies listed on the Indonesia Stock Exchange which became the population of this research. In choosing the samples, the researcher used a non-probability sampling method with purposive random sampling. Purposive random sampling was done by determining the samples from respondents whom the researchers assumed to have the desired characteristics or qualification. To see the impact of the implementation of the IFRS convergence on the value of the company, the researchers compared the value of the company before and after the implementation of convergence. Therefore, the observation periods were 2011 (before the convergence) and 2013 (after the convergence). In the preliminary surveys, it was found out that not all companies had the data on both periods. It was due to several factors such as some companies were not yet, registered or some companies were in suspended status on IDX.

Methods of Analysis: To analyze the data, the researchers used descriptive statistics and inferential statistics. Descriptive statistics is the statistics that describes the phenomenon that attracts attention and is intended to illustrate and presents in a concise information on large amounts of data and variables (Sekaran, 2006). Through a statistical descriptive analysis, the researchers transformed raw data into a form which described a series of factors in a state that includes the 
average (mean), variant standard deviation, median, mode, range and so on. Meanwhile, the use of inferential statistics or inductive is intended to make an inference (predictions or decision) of a population based on information of a sample. In other words, the inferential statistics is able to infer from the population to the sample. In conducting the data analysis, the researchers used two main types of tests, namely, data analysis and hypothesis testing. Variables that were examined are as follow: Y: Market Value of Equity (MVE) and its determinant $\mathrm{X}_{1}$ : Equity Per Share (EQPS) $\mathrm{X}_{2}$ : Earning Per Share (EPS) $\mathrm{X}_{3}$ : Price Per Share (PPS).

\section{RESULTS AND DISCUSSION}

At first, the researchers found that there were 96 companies in 2011 and 99 companies in 2013. The difference in the amount of the company occurred because there was a difference in the activity of the company in the exchange for example those which experienced a postponement in the stock exchange so that by 2013 their shares could not be traded or were not traded yet in 2011. Of these, there was only a number of 77 companies that consistently traded stocks in 2011 and 2013. Furthermore, the number of the companies reduced to only 54 companies by the time when the researchers resorted the data and found some companies that had very different data from others such as the difference between the data of 2011 and 2013 was quite far (one was positive and the other one was negative). The researchers categorized those data as outlier data. Therefore, they were not included in further testing. The data of 54 companies which were then processed further. Based on the results of the descriptive statistics in Table 1 , it is visible that the average value of MVE, EPS, EQPS and PPS changed after 2013. For both MVE and EQPS, the average rose to 66.49 and $128.48 \%$.

Meanwhile, for EPS and PPS, both average values decreased into 10.43 and $18.49 \%$. These results indicate that there was a change in the value after the convergence of IFRS whether the rise of value as in EQPS and MVE or decline in value as in EPS and PPS. However, to determine whether the difference in value was significant or not the test was then continued to the test of the difference and the test of the correlation and test data before and after the convergence of IFRS. Before performing the data analysis, researchers first conducted a series of classic assumption test to determine whether there was a sign of deviation of the data and to ensure the structural equation model was BLUE (best linear unbiased estimator). In this research, the researchers conducted five classic Assumption tests, namely: normality, multicollinearity, heteroscedasticity, autocorrelation and linearity.
Table 1: The description of the changes on the value of the company after the convergence of IFRS

\begin{tabular}{llc}
\hline Paired samples statistics & Mean & N \\
\hline Pair 1 & & \\
MVE_2011 & 44797.3148 & 54 \\
MVE_2013 & 74584.0926 & 54 \\
Pair 2 & & \\
EPS_2011 & 99.8139 & 54 \\
EPS_2013 & 89.3096 & 54 \\
Pair 3 & & \\
EQPS_2011 & 350.6646 & 54 \\
EQPS_2013 & 801.2335 & 54 \\
Pair 4 & & \\
PPS_2011 & 1943.7222 & 54 \\
PPS 2013 & 1584.2963 & 54 \\
\hline Prepar
\end{tabular}

Prepared from secondary data with Eviews V.9.0

Table 2: The results of Kolmogorov-Smirnova normality test

\begin{tabular}{ll}
\hline One Kolmogorov-Smirnova test & Understandardized residual \\
\hline $\mathrm{N}$ & 107 \\
Normal parameters & 3D \\
Mean & 0.00 \\
$\mathrm{SD}$ & 0.59 \\
Most extreme & \\
Absolute & 0.06 \\
Differences & \\
Positive & 0.09 \\
Negetive & $(0.04)$ \\
Test statistic & 0.06 \\
Asymp.Sig.(2-talled) & $0.200^{\mathrm{cd}}$ \\
\hline
\end{tabular}

${ }^{c d}$ Prepared from secondary data with SSS $23 \mathrm{~V}$

Normality test: A good model is the one that has a normally distributed residual value. Therefore, the test of normality is not done on each variable but on the residual. For the testing methods the researchers used of Kolmogorov-Smirnova test and Jarque-Bera histogram test (Table 2 and 3 and Fig. 1).

The results showed that the value of Asymp. Sig. (2-tailed) was $0.20 .05>$ (Kolmogorov-Smirnova test) and for the Jarque-Bera test, the JB probability value was $0.510>0.05$. This means that the residual research data came from its normal population and the regression models met the assumption of normality.

Multicollinearity test: This test was done to find out whether or not there was a strong correlation among independent variables in a multiple linear regression model. The testing method used in this research was the Variance Inflation Factor (VIF) and Tolerance (TOL). The results showed that for all TOL variable values were $>0.10$ and VIF values were $<10$. This means that there was not a multicollinearity on the research data.

Heteroscedasticity: This test was done to find out whether in a regression model, a variant of residual inequalities of one observation to other observations occurs. A good regression model is a model which is homoscedastic or that heteroscedasticity does not occur. In other words, the residues of observations to other observations remain or error has the same variant. The 
The Soc. Sci., 14 (1): 1-8, 2019

Table 3: Multicollinearity test results

\begin{tabular}{|c|c|c|c|c|c|c|c|}
\hline \multirow[b]{2}{*}{ Model } & \multicolumn{2}{|c|}{ Understanderdized coefficients } & \multicolumn{3}{|c|}{ Standerdized coefficients } & \multicolumn{2}{|c|}{ Collinerarity statistics } \\
\hline & $\mathrm{B}$ & SE & Beta & $\mathrm{t}$-values & Sig. & Tolerance & VIF \\
\hline 1 (Constant) & $8,467.07$ & $12,932.18$ & & & & 0.65 & 0.51 \\
\hline EPS & (99.16) & 77.56 & $(0.13)$ & $(1.28)$ & 0.20 & 0.55 & 1.83 \\
\hline EQPS & 11.72 & 9.56 & 0.11 & 1.23 & 0.22 & 0.70 & 1.43 \\
\hline PPS & 30.53 & 3.85 & 0.70 & 7.94 & 0.00 & 0.68 & 1.46 \\
\hline
\end{tabular}

Prepared from secondary data with SSS $23 \mathrm{~V}$

Table 4: Glejser test results for heteroscedasticity

\begin{tabular}{lclcl}
\hline Items & Coefficient & Items & Coefficient & Conclusion \\
\hline F-statistic & 1.35 & Prob. F $(3,104)$ & 0.26 & $0.26>0.05$ \\
Obs* ${ }^{2}$ & 4.04 & Prob.Chi square (3) & 0.26 & Heteroscedasticity does not occure \\
Scaled explained & 4.16 & Prob.Chi square (3) & 0.24 & \\
\hline
\end{tabular}

Prepared from secondary data with SSS $23 \mathrm{~V}$

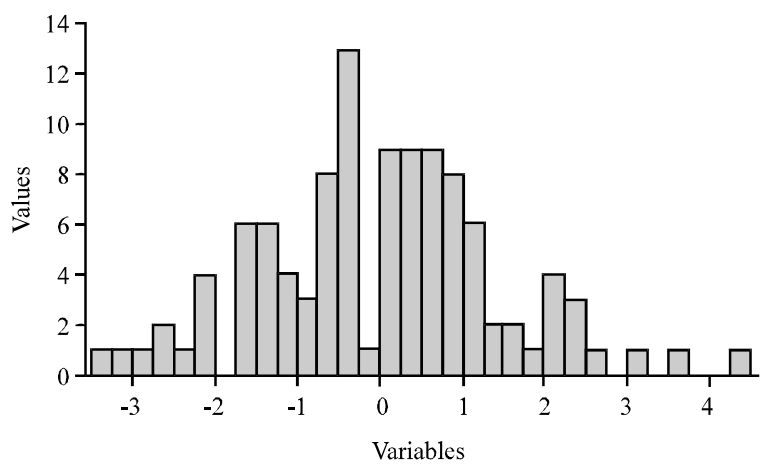

\begin{tabular}{ll}
\hline \multicolumn{2}{l}{ Series: Residuals } \\
Sample 1108 \\
Observations 108 \\
Mean & $1.048 \mathrm{e}-16$ \\
Median & 0.084244 \\
Maximum & -3.421835 \\
SD & 1.443116 \\
Skewness & 0.212600 \\
Kurtosis & 3.343112 \\
Jarque-Bera & 1.343346 \\
Probability & 0.510853 \\
\hline
\end{tabular}

Fig. 1: The results of Jarque-Bera normality test

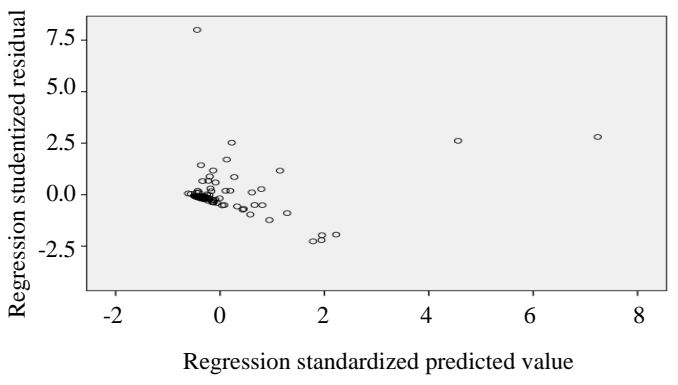

Fig. 2: Results of scatterplot test for heteroscedasticity: prepared from secondary data with $\operatorname{SSS} 23 \mathrm{~V}$ (Dependent variables: MVE)

testing method used in this research was the method of the scatterplot and was reinforced with Glejser test. Through the scatterplot figure, it could be seen that the dots did not form a particular regular pattern (wavy, widens or narrows). Even so, most of those dots were seen gathered in one place, so, the researchers suspected a little sign of heteroscedasticity on the research data (Fig. 2 and Table 4).

However, through the Glejser test, it was found out that the value of the probability F-0.26 was $>0.05$. This means that there was not any heteroscedasticity on the research data. For more sturdy (robust) results of the regression models, the researchers decided that the analysis model was made in the form of the equation of a regression of log-linear.

Autocorrelation test: This test was done to find out whether or not there was a correlation between time $t$ and time $\mathrm{t}-1$. The test method used was the Breusch-Godfrey (Table 5). From the results of the Breusch-Godfrey test, it was found out that the value of the prob. F-stat 0.8394 was $>0.05$. This means that there was no autocorrelation on the research data. This was confirmed by the test results of the Durbin-Watson, i.e., 1.88>1.68 (table dU) but $>4-\mathrm{dU}(4-1.68=2.32)$.

The linearity test: This test was done to determine whether or not two variables have a linear relationship not significantly. The testing methods used in this research was the Ramsey test. From the results of Ramsey test, it was found out that the value of prob. F-stat was $0.70>\mathrm{Sig}$. $\alpha 0.05$. This means that the regression equation models have met the assumption of linearity. Based on the results of all classical assumptions tests above, it was concluded that research data were already eligible or passed all the testing. Thus, this research data could be included in further testing (Table 6 and 7). 
Table 5: the results of the Breusch-Godfrey test Breusch-Godfrey serial correlation LM test:

\begin{tabular}{lr} 
Variables & Values \\
\hline F-statistic & 0.175315 \\
Obs*R $^{2}$ & 0.369983 \\
Prob. F $(2,102)$ & 0.839400 \\
Prob. Chi-square (2) & 0.831100 \\
\hline Prepared from secondary data with Eviews V.9.0; Test equation; Dependent \\
variable: RESID method: Least squares; Date: $09 / 05 / 16 ;$ Time: $15: 39 ;$ \\
Sample: 1 108; Included observations: $108 ;$ Presample missing value lagged \\
residuals set to zero
\end{tabular}

Table 6: the ramsey test results

\begin{tabular}{|c|c|c|c|}
\hline Variables & Values & $\mathrm{df}$ & Probability \\
\hline t-statistic & 0.526449 & 103 & 0.5997 \\
\hline F-statistic & 0.277148 & $(1,103)$ & 0.5997 \\
\hline Likelihood ratio & 0.290212 & 1 & 0.5901 \\
\hline \multicolumn{4}{|c|}{$\begin{array}{l}\text { Equation: Untitled; Specification: } \log (\mathrm{Y}) \mathrm{C} \log \left(\mathrm{X}_{1}\right) \log \left(\mathrm{X}_{2}\right) \log \left(\mathrm{X}_{3}\right) \text {; } \\
\text { Omitted variables: squares of fitted values }\end{array}$} \\
\hline \multicolumn{4}{|c|}{ Table 7: Test summary } \\
\hline Variables & Sum of sq. & $\mathrm{df}$ & Mean squares \\
\hline Test SSR & 0.597990 & 1 & 0.597990 \\
\hline Restrict & & 104 & 2.142658 \\
\hline Unrestricted SSR & 222.2384 & 103 & 2.157654 \\
\hline
\end{tabular}

Prepared from secondary data with eviews V.9.0

The difference of the company values before and after the IFRS convergence: To test whether there was a difference in the average value among earning per share, equity per share, the price per share and the market value of equity before and after the application of the IFRS, the researchers did a paired-sample t-test. The paired-sample t-test was done for both sides because the researchers wanted to find out whether the average value before and after the IFRS convergence were the same or not. The testing method used in this research was the paired t test which was of the following provisions 1 . If $\mathrm{p}$ value Sig. is $>0.05$, then $\mathrm{H}_{0}$ and $\mathrm{H}_{\mathrm{a}}$ was rejected and 2 . If $\mathrm{p}$ value $\mathrm{Sig}$. is $=0.05$, then $\mathrm{H}_{0}$ denied and $\mathrm{H}_{\mathrm{a}}$ is received. Based on the results of the paired-sample t-test for MVE value, the p-value Sig. was 0120 that is $>0.05$, then the zero hypothesis $\left(\mathrm{H}_{0}\right)$ was accepted and the alternative hypothesis $\left(\mathrm{H}_{\mathrm{a}}\right)$ was rejected. This means that the average Market Value of Equity (MVE) before and after the application IFRS did not differ statistically. Similarly, for EPS value, it was found out that the p-value Sig. was 0.78 which was $>0.05$, then the zero hypothesis $\left(\mathrm{H}_{0}\right)$ was accepted and the alternative hypothesis $\left(\mathrm{H}_{\mathrm{a}}\right)$ was rejected. This means that the average value of Earning Per Share (EPS) before and after the application of the IFRS did not differ statistically. For EQPS value, the p value Sig. was 0.09 which was $>0.05$, then the zero hypothesis $\left(\mathrm{H}_{0}\right)$ was accepted and the alternative hypothesis $\left(\mathrm{H}_{\mathrm{a}}\right)$ was rejected. This means that the average value of Equity Per Share (EQPS) before and after the application of the IFRS did not differ statistically (Table 8). The last is PPS value. From the paired sample t-test, it was found out that the p-value Sig. was 0.28 which was $>0.05$, then the zero hypothesis $\left(\mathrm{H}_{0}\right)$ was accepted and the alternative hypothesis $\left(\mathrm{H}_{a}\right)$ was rejected. This means that the average value of Price Per Share (PPS) before and after the implementation of the IFRS did not differ statistically.

Therefore, it can be concluded that for all the variables examined, there was no significant difference between the influence of before and after the implementation of IFRS on the average values of earning per share $\left(\mathrm{X}_{1}\right)$, equity per share $\left(\mathrm{X}_{2}\right)$, the price per share $\left(\mathrm{X}_{3}\right)$ and the market value of equity $(\mathrm{Y})$ of trading companies listed on the Jakarta stock exchange. In other words, the application of IFRS accounting standards did not provide a significant impact upon the average change in earning per share, equity per share, the price per share and the market value of equity.

In addition to testing the differences, the researchers also calculated the correlation between the values before and after the application of IFRS for each variable (Table 9). The value of $\mathrm{R}^{2}$ correlation of the table shows the magnitude of the contribution of the implementation of IFRS to the establishment of the value of each variable. The interpretation over the value of $\mathrm{R}^{2}$ indicates that the implementation of IFRS contributed over the formation of the value of the MVE of $37.7 \%$ while the rest were caused by other factors. Because the Sig. 0.000 was $<0.05$, then there was an MVE relationship, then there are before and after the application of IFRS. For EPS variables, it was visible that the IFRS implementation contributed over the formation of the value EPS of $0 \%$, while the rest were caused by other factors. Because the Sig. 0.989 was $>0.05$, then there was no relationship of EPS before and after the application of IFRS. Next, the convergence of IFRS contributed over the formation of the EQPS value of $3.46 \%$ while the rest were caused by other factors. Because the Sig. 0.177 was $>0.05$, then there was no relationship of EQPS before and after the application of IFRS. The last variable is PPS. The implementation of IFRS contributed over the formation of the value of the PPS of $68,72 \%$ while the rest were caused by other factors. Because the Sig. 0.000 was $<0.05$, then there was a relationship of PPS before and after the implementation of IFRS.

These results are consistent with previous inventions (Callao et al., 2007) which found no improvements in the relevance of the financial reporting for the local stock market operator because of the gap between the book value and the broader market when IFRS was applied. Meanwhile, there was no advantage in terms of the usefulness of financial reporting in the short term. The increase can be achieved in the medium to long term. This is supported by Hung and Subramanyam (2007) who assert that the book value is not affected by IFRS as 
Table 8: The results of paired-sample t-test

$$
\text { Paired differences }
$$

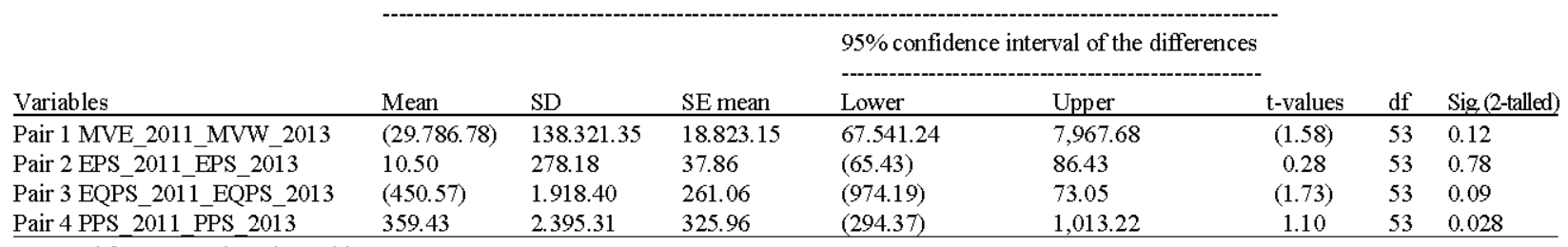

Prepared from secondary data with SSS $23 \mathrm{~V}$

Table 8: The correlation between the application of IFRS and the variables -------------Jalur Hubungan----------- N N Correlation (r) $\mathrm{R}^{2}(\%)$ Sig. \begin{tabular}{llllll}
\hline Pair 1 & MVE_2011 and MVW_2013 & 54 & 0.614 & 37.70 & 0.000
\end{tabular} $\begin{array}{llllll}\text { Pair } 2 \text { EPS_2011 and EPS_2013 } & 54 & 0.002 & 0.000 & 0.989\end{array}$ $\begin{array}{llllll}\text { Pair } 3 & \text { EQPS } 2011 \text { and EQPS } 2013 & 54 & 0.186 & 3.460 & 0.177\end{array}$ $\begin{array}{llllll}\text { Pair } 4 \text { PPS 2011 and PPS_2013 } & 54 & 0.829 & 68.72 & 0.000\end{array}$ Prepared from secondary data with SSS $23 \mathrm{~V}$

well as (Terzi et al., 2013) which found that there were no statistically significant differences in GAAP-based market value and IFRS-based financial reports. In this research, the use of data in a short span of time both before and after the convergence could be a cause of the invisibility of a significant difference. The impacts of standard changes might be experienced in a longer period of time.

\section{CONCLUSION}

In this research, some conclusions were drawn. In trading companies listed on Jakarta Stock Exchange, MVE, EPS, EQPS and PPS had no significant difference before and after the application of the IFRS. However, the correlation test results indicated that the convergence of IFRS was related to the formation of the market value of equity and the price per share value after the application of IFRS but did not contribute over the formation of the value of earning per share and equity per share after IFRS. The shortage in this research was that the data only covered one sector companies in Indonesia stock exchange and a short observation time span. Therefore, the effect of the changes has not yet, to be felt. It is expected this research can be further improved by adding other sectors with more data and a longer time.

\section{REFERENCES}

Arfan, I., 2008. [Method of Accountancy Accounting Research]. 1st Edn., Graha Ilmu, Yogyakarta, Indonesia, (In Indonesian).

Ashbaugh, H. and M. Pincus, 2001. Domestic accounting standards, international accounting standards and the predictability of earnings. J. Acc. Res., 39: 417-434.
Ayu, W., 2014. [Influence of accounting information and Macro economy to value of Syariah securities company]. Master Thesis, Universitas Negeri Surabaya, Surabaya.

Ball, R. and L. Shivakumar, 2005. Earnings quality in UK private firms: Comparative loss recognition timeliness. J. Account. Econ., 39: 83-128.

Ball, R., A. Robin and J.S. Wu, 2003. Incentives versus standards: Properties of accounting income in four East Asian countries. J. Account. Econ., 36: 235-270.

Bambang, S., 2010a. [Business Research Methods]. Alfabeta, Bandung, Indonesia, (In Indonesian).

Bambang, S., 2010b. [The role of corporate performance in determining the influence of macroeconomic fundamental factors, systematic risk and corporate policy on corporate value]. Master Thesis, Universitas Diponegoro, Semarang, Indonesia. (In Indonesian)

Barth, M.E., 2008. Global financial reporting: Implications for US academics. Accounting Rev., 83: 1159-1179.

Blanchette, M. and A. Desfleurs, 2011. Critical perspectives on the implementation of IFRS in Canada. J. Global Bus. Administration, 3: 19-40.

Burgstahler, D.C., L. Hail and C. Leuz, 2006. The importance of reporting incentives: Earnings management in European private and public firms. Accounting Rev., 81: 983-1016.

Butler, M., A.J. Leone and M. Willenborg, 2004. An empirical analysis of auditor reporting and its association with abnormal accruals. J. Account. Econ., 37: 139-165.

Cairns, D., 1999. Applying International Accounting Standards. 2nd Edn., Butterworth, London, England, UK., ISBN:9780406924261, Pages: 1045.

Callao, S., J.I. Jarne and J.A. Lainez, 2007. Adoption of IFRS in spain: Effect on the comparability and relevance of financial reporting. J. Int. Accounting, Auditing Taxation, 16: 148-178.

Chee, H.K., L.K. Phua and D.L.I. Yau, 2016. The relationship between audit quality, board independence and audit committee independence on earnings management before and after full convergence of IFRS. Social Sci., 11: 4902-4906. 
Choi, F.D.S. and G.K. Meek, 2005. International Accounting. 5th Edn., Pearson Prentice Hall, Upper Saddle River, New Jersey, USA., ISBN: 9780131480971, Pages: 503.

Choi, F.D.S., C.A. Frost and G.K. Meek, 1999. International Accounting. 3rd Edn., Prentice-Hall, New Jersey, USA., ISBN9780132607612, Pages: 479

Chua, W.F. and S.L. Taylor, 2008. The rise and rise of IFRS: An examination of IFRS diffusion. J. Accounting Publ. Policy, 27: 462-473.

Collemi, S.A., 2011. International Financial Reporting standards (IFRS): Implications on the US extractive industry. Pet. Accounting Financial Manage. J., 30: $1-16$.

Daske, H. and G. Gebhardt, 2006. International financial reporting standards and experts perceptions of disclosure quality. Abacus, 42: 461-498.

Daske, H., L. Hail, C. Leuz and R. Verdi, 2008. Mandatory IFRS reporting around the world: Early evidence on the economic consequences. J. Acc. Res., 46: 1085-1142.

Hung, M. and K.R. Subramanyam, 2007. Financial statement effects of adopting international accounting standards: The case of Germany. Rev. Accounting Stud., 12: 623-657.

Husein, U., 2010. [Design Strategic Management Research]. 1st Edn., Rajagrafindo Persada, Jakarta, Indonesia, (In Indonesian).

Jermakowicz, E.K. and B.J. Epstein, 2008. Joining the World: US companies adopting IFRS. Butterworths J. Intl. Banking Financial Law, 1: 609-612.
Nobes, C. and R. Parker, 2010. Comparative International Accounting. 11th Edn., Prentice Hall, Upper Saddle River, New Jersey, USA., ISBN: 9780273725626 , Pages: 637.

Ohlson, J.A., 1995. Earnings, book values and dividends in equity valuation. Contemporary Account. Res., 11: 661-687.

Sekaran, U., 2006. Research Method for Business, a Skill Building Approach. 4th Edn., Wiley India Pvt Ltd, New Delhi, India, ISBN: 9788126509287 , Pages: 464.

Soemarso, S.R., 1992. [An Introduction to Accounting Book One]. 4th Edn., PT. Rineka Cipta, Jakarta, Indonesia, (In Indonesian).

Street, D. and S. Gray, 2001. Observance of international accounting standards: Factors explaining non-compliance by companies referring to the use of IAS. Association of Chartered Certified Accountants, London, England, UK.

Syofian, S., 2010. [Descriptive Statistics for Research]. Raja Grafindo Perkasa, Jakarta, Indonesia, (In Indonesian).

Terzi, S., R. Oktem and I.K. Sen, 2013. Impact of adopting international financial reporting standards: Empirical evidence from Turkey. Intl. Bus. Res., 6: 55-66.

Tsalavoutas, I. and L. Evans, 2010. Transition to IFRS in Greece: Financial statement effects and auditor size. Managerial Auditing J., 25: 814-842. 